\title{
Ks. Adolf Józef Bożeniec Jełowicki (1863-1937). Pierwszy Polak w jerozolimskiej szkole biblijnej
}

\author{
Rev. Adolf Józef Bożeniec Jełowicki (1863-1937). \\ The First Pole at the École Biblique in Jerusalem
}

\author{
JAROSŁAW ROMAN MARCZEWSKI \\ Sekcja Historii Kościoła i Patrologii, Katolicki Uniwersytet Lubelski Jana Pawła II \\ e-mail:jmarcz@kul.pl \\ ORCID: 0000-0002-7021-6806
}

\begin{abstract}
The aim of this paper is to discuss and answer for the first time the question of the earliest Polish presence at the École biblique et archéologique française de Jérusalem. As an outcome of archival research carried out at the Dominican Priory of St. Stephen in Jerusalem following conclusions can be drawn. First of all, the attendance of Poles at the École biblique dates back to the very beginning of the school. As early as in 1892 that is only two years after its first commencement a Polish priest from the Archdiocese of Warsaw, Rev. Adolf Józef Bożeniec Jełowicki started his biblical studies there. He had an occasion to meet in person the founder of the school and the famous professor Fr. Marie-Joseph Lagrange. Rev. Jełowicki was also a witness to the creation of the important periodical Revue Biblique. Lectures at that time were few, and in the process of studying, the emphasis was put not only on theoretical knowledge, but also on discovering the Holy Land through practical classes in archeology and topography. Lastly, the stay of Rev. Jełowicki at the École biblique was only one year long nevertheless it resulted in the publication of a professional guide to Jerusalem and its surroundings, as well as several dozen encyclopedic entries on biblical topics. However, after returning to the homeland, Rev. Jełowicki could not pursue an academic career path, but the lessons learned at the École biblique became his important asset to future pastoral challenges as a rector in Warsaw, and then as an auxiliary bishop in Lublin.
\end{abstract}

KEywords: Adolf Józef Bożeniec Jełowicki, École biblique et archéologique française de Jérusalem, Polish clergy

SŁowa KLucze: Adolf Józef Bożeniec Jełowicki, Francuska Szkoła Biblijna i Archeologiczna w Jerozolimie, duchowieństwo polskie

E rancuska Szkoła Biblijna i Archeologiczna w Jerozolimie (École biblique et archéologique française de Jérusalem) - jeden z najbardziej znanych i zarazem znaczących ośrodków badań biblijnych, zwłaszcza w zakresie archeologii biblijnej oraz egzegezy - funkcjonuje już od 130 lat. Ta wystarczająco długa historia zachęca do bliższego przyjrzenie się jej dziejom i to nie tylko pod kątem dorobku naukowego, ale także specyfiki dydaktycznej i organizacyjno-admini- 
stracyjnej. W ten kontekst wpisane są rzesze profesorów i studentów, których akademickie losy warto prześledzić.

Spojrzenie na szkołę z perspektywy historycznej w znacznej mierze umożliwia świeżo uporządkowane archiwum uczelni i powiązanego z nią klasztoru św. Szczepana (Couvent Saint-Etienne de Jérusalem). Sięgnięcie do materiałów dokumentacyjnych stało się stosunkowo łatwe dzięki kilkuletniemu wytężonemu i kompetentnemu zaangażowaniu Hélène Rigaud, która fachowo opracowała materiały archiwalne i przygotowała stosowny inwentarz.

Dla polskich biblistów, ale zapewne także szerokiego grona rodzimych teologów innych specjalności, szczególnie interesujące mogą być informacje dotyczące pobytu naszych rodaków w szkole jerozolimskiej. Okazuje się, że obecność ta zaznaczyła się bardzo wcześnie, jeszcze w ostatniej dekadzie XIX stulecia. Pierwszym Polakiem, który skorzystał z akademickiej propozycji już u samych początków funkcjonowania uczelni, był ks. Adolf Józef Bożeniec Jełowicki. Efekty kwerendy dotyczącej jego pobytu w szkole jerozolimskiej zostaną przedstawione w niniejszym artykule.

\section{Przyszły student}

Adolf Józef Bożeniec Jełowicki urodził się 25 lutego 1863 r. w Warszawie w kresowej rodzinie ziemiańskiej Adolfa i Pauliny z Sobańskich. Ojciec miał za sobą karierę w Wojsku Polskim, w którym służył w randze oficerskiej, a za udział w powstaniu listopadowym otrzymał order Virtuti Militari. Matka była znaną warszawską działaczką aktywną na polu charytatywnym. Przodkowie zarówno ze strony ojca, jak i matki należeli do stanu szlacheckiego i piastowali w dobie staropolskiej urzędy ziemskie. Liczne rodzeństwo przygotowywane było do objęcia w przyszłości własnych majątków i zaangażowanej pracy na niwie społecznej. Znakomite warunki domu rodzinnego zapewniły młodemu Jełowickiemu podstawowy szlif wychowawczy i dydaktyczny. Uczęszczał także do szkoły realnej w Warszawie, którą ukończył w 1880 r. Edukację na poziomie wyższym, choć uczelnia nie miała formalnie charakteru akademickiego, odbył najpierw w Instytucie Gospodarstwa Wiejskiego i Leśnictwa w Puławach, finalizując ten etap nauki w $1883 \mathrm{r}$. W kolejnych latach studiował przedmioty humanistyczne w Brukseli oraz odbywał podróże po Europie, pielgrzymując m.in. do Rzymu na jubileusz pięćdziesięciolecia kapłaństwa papieża Leona XIII. W 1887 r., idąc za głosem odkrytego powołania, wstąpił do Seminarium Duchownego św. Jana Chrzciciela w Warszawie. Po dwóch latach, z uwagi na prezentowany wysoki poziom intelektualny i osobowościowy, przełożeni zdecydowali o wysłaniu alumna do Lowanium, aby na tamtejszym uniwersytecie katolickim dopełnił studiów 
teologicznych. Ze względu na ultimatum postawione przez generała gubernatora warszawskiego Iosifa Władimirowicza Hurkę, o konieczności przygotowywania się do kapłaństwa w kraju lub przymusowym pozostaniu na stałe za granicą, Jełowicki zdecydował się na powrót do Warszawy. W dniu 7 grudnia 1890 r. przyjął święcenia kapłańskie z rąk arcybiskupa warszawskiego Wincentego Chościak Popiela. W kolejnych dwóch latach pełnił obowiązki wikariusza - krótko w Łęczycy, a następnie w parafii pw. Narodzenia NMP w Warszawie na Lesznie ${ }^{1}$.

Duszpasterskie zaangażowanie ks. Jełowickiego nie wyczerpywało jego potencjału, a zapewne także ambicji osobistych i familijnych. Dalsza ścieżka awansów kościelnych wydawała się czymś naturalnym. Niemniej jednak na tym wczesnym etapie posługiwania warto było pogłębić jeszcze przygotowanie w zakresie umysłowej formacji kapłańskiej. Jedyną uczelnią w państwie rosyjskim mającą charakter szkoły wyższej, gdzie wykładano nauki kościelne, była Cesarska Rzymskokatolicka Akademia Duchowna w Petersburgu, działająca w stolicy imperium od $1842 \mathrm{r}^{2}$ Była ona jednak w zasadzie przeznaczona dla alumnów i nie prowadziła specjalistycznego kursu dla księży, którzy już ukończyli edukację na poziomie seminaryjnym. W tych okolicznościach ks. Jełowicki podjął starania o wyjazd na studia uzupełniające do Jerozolimy. Bardzo trudne warunki funkcjonowania Kościoła w rosyjskim reżimie zaborczym stanowiły naturalną przeszkodę dla realizacji tych planów. Otrzymanie paszportu na wyjazd zagraniczny przez polskiego duchownego było niezwykle skomplikowane. Władze starały się uzyskać pewność, że podróżujący nie odwiedzi zwłaszcza ważnych ośrodków życia religijnego pod innymi zaborami ani nie uda się do Stolicy Apostolskiej ${ }^{3}$. Kierunek, jakim była Ziemia Święta, stanowiący wartość także

Akta osobowe bpa Adolfa Józefa Bożeńca Jełowickiego (Archiwum Archidiecezjalne Lubelskie, sygn. Rep 60 B IIb J31) 25, 125.

2 I. Wodzianowska, Rzymskokatolicka Akademia Duchowna w Petersburgu 1842-1918 (Lublin: Towarzystwo Naukowe KUL 2007).

3 Dla porównania warto prześledzić wspomnienia duchownych, którzy opisali osobiste doświadczenia dotyczące starań i wyjazdu za granicę, np. K. Dębiński, Z przeżytych chwil. Cz. 1 (maszynopis, Bibliotka Metropolitalnego Seminarium Duchownego w Lublinie, bez sygn.) 198-199: „Po ukończeniu Akademii Petersburskiej w 1885 r. [...] przystąpiłem do realizowania swoich marzeń studenckich, a przede wszystkim do odwiedzenia Rzymu, zobaczenia Ojca św. i otrzymania odeń błogosławieństwa na dalsze życie i pracę. [...] Otrzymanie w owym czasie paszportu zagranicznego od rządu rosyjskiego, jeśli o takowy starał się kapłan katolicki, nie było rzeczą łatwą, musiał bowiem udowodnić, że jest ciężko chorym i że bez leczenia np. w Karlsbadzie obejść się nie może. Jakkolwiek cieszyłem się najlepszym zdrowiem, zacni lekarze znaleźli u mnie kamienie żółciowe i zalecili bezwarunkowy wyjazd do Karlsbadu. Władza diecezjalna z odpowiednią odezwą przesłała świadectwo lekarskie do warszawskiego generał-gubernatora i po kilku miesiącach otrzymałem pozwolenie wyjazdu do Karlsbadu na 28 dni, na zwykłych warunkach. Warunki te opiewały, iż przed otrzymaniem paszportu mam złożyć w kancelarii gubernatora lubelskiego deklarację, iż pojadę do Karlsbadu najkrótszą drogą, iż po drodze nigdzie dłużej zatrzymywać się nie będę i że pod żadnym pozorem nie będę w Rzymie, we Lwowie i w Krakowie. W początkach lipca 1894 r. dałem żądaną deklarację, paszport otrzymałem, a przejechawszy kordon rosyjski w Granicy i ubrawszy się po cywilnemu, puściłem się najprostszą drogą do Rzymu". 
w oczach carskiego prawosławia, mógł zostać łatwiej zaakceptowany. Niemniej jednak w ramach całokształtu carskiej polityki wyznaniowej i narodowościowej pójście drogą zwykłych procedur urzędniczych z pewnością nie przyniosłoby oczekiwanych rezultatów. O uzyskaniu paszportu musiała w tym wypadku zadecydować pozycja społeczna Jełowickich, a być może także szereg nieformalnych zabiegów, do których przyzwyczajeni byli rosyjscy czynownicy na każdym szczeblu hierarchii.

\section{Szkoła i odbywane zajęcia}

Gdy ks. Jełowicki miał przybyć do Jerozolimy, tamtejszy konwent oo. Dominikanów funkcjonował zaledwie od ośmiu lat. Szkoła biblijna szykowała się zaś do rozpoczęcia dopiero trzeciego cyklu wykładów akademickich od chwili swojego założenia w 1890 r. $^{4}$

Klasztor św. Szczepana został usytuowany w domniemanym miejscu śmierci pierwszego męczennika, gdzie cesarzowa Eudokia kazała w połowie V stulecia wystawić bazylikę poświęconą czci świętego diakona. W końcu XIX w. z bazyliki - która przechodziła burzliwe koleje dziejów - pozostały już tylko ruiny. Szkoła natomiast ruszyła początkowo w zaadaptowanym na ten cel budynku dawnej rzeźni miejskiej, zupełnie nieprzystosowanym do prowadzenia zajęć naukowych ${ }^{5}$. Wedle wspomnień pierwszych studentów jedyna sala wykładowa nie miała okien, a światło wpadało do jej wnętrza wyłącznie przez drzwi. Przy jednym stole ciasno siedzieli nieliczni uczniowie, na ścianie wisiała jedyna dostępna mapa, a na wyposażenie klasy składała się jeszcze tablica do pisania kredą. Była ona zresztą gęsto zapisana na stałe - a to $z$ braku podręczników - różnymi alfabetami semickimi, formami podstawowymi części mowy oraz zasadami gramatycznymi ${ }^{6}$.

Założyciel szkoły - o. Marie-Joseph Lagrange - miał w zamyśle uczynienie z niej praktycznego studium i taką też nazwę nadał zorganizowanej przez siebie instytucji - Szkoła Praktyczna Studiów Biblijnych (École pratique d'études bibliques). Szkoła nie była i nie miała być uniwersytetem języków orientalnych ani innym rodzajem uniwersytetu kopiującym znane wzorce europejskie. Miała natomiast dawać znajomość Ziemi Świętej i Biblii oraz języków ściśle przydatnych do egzegezy Pisma Świętego. Zatem szkoła miała prowadzić po części krytyczną analizę tekstów (krytyka tekstualna, literacka i historyczna), po części zaś kon-

\footnotetext{
B. Montagnes, Marie-Joseph Lagrange. Une biographie critique (Paris: Cerf 2004) 60-67.

M.-J. Lagrange, „Chronique. Après vingt-cinq ans”, $R B 12$ (1915) 248.

L.-H. Vincent, „Le Père Lagrange”, RB 47 (1938) 334.
} 
frontować teksty z rzeczywistością lokalną (geografia, archeologia, epigrafia, etnologia) $)^{7}$. Założyciel szkoły widział ponadto potrzebę ścisłego połączenia studiów z życiem duchowym - a więc klasztoru, który miał dawać szkole duchowe ramy, ze studium, które dla klasztoru miało być przedmiotem apostolskiej posługi ${ }^{8}$.

Gorliwość o. Lagrange'a w realizowaniu skromnie rozpoczętego dzieła przyniosła dość szybko zaskakujące rezultaty. W grudniu 1891 r. gotowy był już nowy budynek szkolny wraz z pokojami przeznaczonymi na zamieszkanie dla zewnętrznych gości ${ }^{9}$.

Liczba studentów, których w pierwszym roku akademickim było tylko pię$\mathrm{ciu}^{10}$, w roku kolejnym wzrosła do siedemnastu. Nadal byli to jednak zakonnicy dominikańscy i asumpcjoniści mający w Jerozolimie swoją placówkę, znaną jako Notre Dame de France ${ }^{11}$. Dopiero trzeci rok akademicki, w którym do grona studentów dołączył ks. Jełowicki, miał okazać się rzeczywiście obiecujący. Liczba studentów wzrosła do ponad trzydziestu, ale co ważniejsze, doszło do ich zróżnicowania zarówno pod względem narodowości - dotąd byli to wyłącznie Francuzi - jak i przynależności instytucjonalnej. Wśród studentów, poza większością z Francji, była bowiem reprezentowana Hiszpania, Niemcy, Włochy, Austria, Belgia i Polska. W gronie studentów znalazło się trzech księży diecezjalnych - wśród nich ks. Jełowicki ${ }^{12}$.

Kapłani diecezjalni musieli mieć rekomendację od swoich biskupów. Mogli zamieszkać w konwencie św. Szczepana, w Notre Dame de France albo innej instytucji katolickiej ${ }^{13}$. Obowiązywał ich regulamin postępowania podobny do tego, jaki funkcjonował w innych dominikańskich uniwersytetach katolickich $^{14}$. Szkoła otrzymała w tym czasie zachętę i błogosławieństwo papieża Leona XIII. Brewe datowane 17 września 1892 r. miało niewątpliwie istotne znaczenie tak dla samej instytucji i tworzących ją ludzi, jak i dla panującej wśród studentów atmosfery ${ }^{15}$.

Ksiądz Jełowicki trafił do szkoły w pierwszych dniach października 1892 r. W dominikańskiej kronice klasztornej zachowała się bowiem informacja o przybyciu w tym czasie na studia dwóch kapłanów diecezjalnych - francuskiego księdza nazwiskiem Chabot oraz księdza polskiego, którego nazwisko nie zostało odnotowane. W kronice pozostawiono puste miejsce na uzupełnienie tego braku. Być może kronikarz nie potrafił poprawnie zapisać obco brzmią-

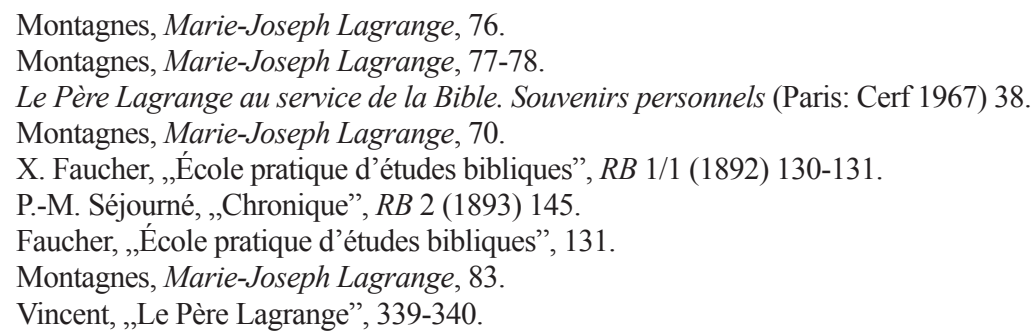


cej godności, a zaniedbania nigdy nie nadrobił. Bez wątpienia chodziło wszakże o ks. Jełowickiego ${ }^{16}$.

Miejscem zamieszkania ks. Jełowickiego był nowy budynek szkolny. Pokoje znajdowały się na pierwszym piętrze, podczas gdy sale wykładowe łącznie z salą konferencyjną były na parterze. Według planów o. Lagrange'a szkoła winna rozpoczynać działalność nazajutrz po obchodach święta Matki Bożej Różańcowej, tj. w poniedziałek po pierwszej niedzieli października. Tak też było w roku akademickim 1892/1893, jako że zajęcia ruszyły 3 października ${ }^{17}$.

Nauka zaczynała się o godz. 10.00. Odbywały się dwa wykłady przed południem, a potem jeszcze dwa lub jeden po południu od godz. 15.15. W poniedziałki o godz. 16.15 wygłaszana była dodatkowo otwarta dla publiczności konferencja tematyczna. Realnie zatem dziennie były 3 lub 4 godziny zajęć w sali wykładowej. We czwartki odbywały się natomiast zajęcia praktyczne w terenie ${ }^{18}$.

Program zajęć, poczynając od roku akademickiego 1891/1892, zaplanowano w cyklu dwuletnim. Ponieważ ks. Jełowicki dołączył do grona studentów od roku 1892/1893, większość zajęć odbywał łącznie z II rokiem, bowiem tylko niektóre były prowadzone osobno dla każdego z roczników. Na zajęcia teoretyczne składały się: wykłady z topografii i historii Jerozolimy (2 godziny), przy czym w pierwszym roku była to Jerozolima Starego Testamentu, a w roku drugim Nowego Testamentu; geografia i historia Ziemi Świętej (2 godziny); archeologia biblijna (1 godzina), z tego w pierwszym roku archeologia Starego Testamentu i epigrafia semicka, a w drugim roku archeologia Nowego Testamentu; egzegeza biblijna (2 godziny), w tym w pierwszym roku egzegeza Starego Testamentu, a w drugim roku egzegeza Nowego Testamentu; język hebrajski kurs podstawowy ( 2 godziny), zaś na II roku studiów kurs egzegezy miał posłużyć za kurs hebrajskiego; greka biblijna (1 godzina); język arabski kurs podstawowy dla I roku (1 godzina) oraz osobny kurs dla II roku (1 godzina); język asyryjski i babiloński kurs podstawowy (2 godziny). Ponadto zaplanowane były wycieczki i podróże naukowe: dwa spacery tygodniowo po Jerozolimie i okolicach; co miesiąc wycieczka jedno- lub kilkudniowa; w listopadzie wyprawa przewidziana w pierwszym roku cyklu studiów na 12 dni, a w drugim na 8 dni, zaś na wiosnę tak w pierwszym jak i w drugim roku podróż zaplanowana na 20 dni. Po drugim roku nauki studenci mieli powrócić do Europy ${ }^{19}$.

Jak w praktyce wyglądał program zajęć ks. Jełowickiego? Ponieważ w roku akademickim 1892/1893 na zajęcia z egzegezy chodziło 23 studentów, w tym 3 księży, nie ma wątpliwości, że należał do ich grona ks. Jełowicki. Na język

16 Couvent Saint-Etienne de Jérusalem, Registre 1882-1910, rok 1892 (ACSEJ, sygn. 4C/D) bez paginacji.

17 Couvent Saint-Etienne de Jérusalem, Registre 1882-1910, rok 1892.

18 Faucher, „École pratique d'études bibliques”, 130.

19 Faucher, „École pratique d'études bibliques”, 129-130. 
hebrajski dla I roku chodziło 17 osób, w tym 3 księży. Podobnie rzecz się miała z zajęciami z języka arabskiego. Na archeologię i geografię uczęszczali wszyscy studenci. Natomiast zajęcia dotyczące tematyki asyryjskiej zgromadziły tylko 4 słuchaczy, co do których tożsamości trudno o bliższe informacje. W poniedziałkowych konferencjach, których tematyka była rozpisana z góry na cały rok, brali udział wszyscy studenci ${ }^{20}$.

W tym czasie wykładowcami byli: o. Lagrange (egzegeza, archeologia biblijna, epigrafia semicka, język hebrajski), o. Paul-Marie Séjourné (geografia Palestyny i topografia Jerozolimy), o. Etienne Doumeth (język arabski) ${ }^{21}$. Konferencje tematyczne prowadzili natomiast: o. Lagrange, o. Séjourné, o. Louis Heydet, o. Joseph Germer-Durand i o. Leon Cré22.

Wycieczkom naukowym przewodził o. Séjourné. W planie studiów na rok akademicki 1892/1893 na miesiąc listopad przewidziane były do odwiedzenia następujące miejsca: Samaria, Amwas (Emaus), El-Medieh (Modin), Rantis (Arymatea), Tibneh (grobowiec Jozuego), Dżifna, Deir Dibwan, ruiny Aj, Michmasz, Anata (Anatot). Na maj i czerwiec zaplanowano natomiast zwiedzanie takich miejsc, jak: Ras-al-Ajn, Cezarea, Góra Karmel, Nazaret, Tyberiada, Banjas (Cezarea Filipowa), Damaszek, Baalbek (Heliopolis), las cedrowy w Libanie, Bejrut ${ }^{23}$.

Wydaje się, że w zakresie wypraw naukowych plany akademickie ulegały w ciągu roku poważnym korektom. Świadectwem tego stanu rzeczy pozostają artykuły autorstwa ks. Jełowickiego, zamieszczone w polskim dwutygodniku literacko-społecznym wydawanym w Warszawie ${ }^{24}$. Zostały one w późniejszym czasie zebrane i uzupełnione w ramach jednej publikacji książkowej, nabierając charakteru pamiętnika i zarazem krytycznego przewodnika po Ziemi Świętej25. Ksiądz Jełowicki opisał w niej szczegółowo wszystkie te miejsca, które studenci odwiedzili w ramach realizowanych studiów.

Spośród jednodniowych wycieczek odbywanych pieszo każdego tygodnia po Jerozolimie i jej najbliższych okolicach ks. Jełowicki wymienił spacery naukowe do następujących miejsc: Grób Chrystusa wraz z trasą drogi krzyżowej, Wzgórze Świątynne, Syjon chrześcijański, sadzawka Betesda, Muristan, Góra Skopus, wioska Anata, źródło Gichon, sadzawka Siloe, Wzgórze Ofel, Dolina Jozafata, Góra Oliwna, Betania, świeżo odkryte w 1892 r. groby herodiańskie, klasztor

\footnotetext{
20 Séjourné, „Chronique”, 145.

21 Faucher, „École pratique d'études bibliques”, 130.

22 Séjourné, „Chronique”, 145.

23 Faucher, „École pratique d'études bibliques”, 129-130.

24 A.J. Bożeniec Jełowicki, „Sześć dni w Kairze”, KR 26 (1893) 673-678, 705-710; idem, „Przechadzki po Jerozolimie i bliższych jej okolicach”, KR 27 (1894) 6-10, 70-72, 100-102, 139-142, 168-170, 201-203, 239-241, 263-266, 301-302, 338-341, 368-370, 388-390, 422-424, 465-467, 495-497, $520-522,553-555,588-590,620-623,654-656,691-693,716-718,758-759$.

25 A.J. Bożeniec Jełowicki, Przechadzki po Jerozolimie i bliższych jej okolicach (Warszawa: Nakład M. Orgelbranda 1897).
} 
Musalabe, tzw. groby królewskie i kamieniołomy królewskie ${ }^{26}$. W nieco większej odległości od Jerozolimy, co wiązało się z przejazdem powozem lub wierzchem konno, albo na osłach, zwiedził natomiast klasztor Mar Saba, Ain Karem, Betlejem, Herodion, tzw. Stawy Salomona, miejscowości Al-Kubajba i Al-Dżib oraz Hebron $^{27}$. Łącznie w ciągu swojego pobytu ks. Jełowicki wziął udział w 23 jednodniowych naukowych wycieczkach organizowanych przez szkołę ${ }^{28}$.

Dłuższa wyprawa, wpisana w program studiów, odbyła się w dniach 10-19 listopada 1892 r. Była to podróż do Galilei z udziałem o. Sejourné’a, o. Alphonse'a de Vildimberga i trzech diecezjalnych księży studentów, wśród których był ks. Jełowicki ${ }^{29}$.

Natomiast w 1893 r. ze szkoły wyruszyła kilkutygodniowa wyprawa naukowa do Egiptu. Brali w niej udział: dwaj profesorowie w osobach o. Lagrange'a i o. Sejourné'a; trzej inni dominikanie, a mianowicie o. de Vildimberg, o. Vincent Zappletal i o. Jean-Marie Perier; trzej księża diecezjalni studiujący w szkole jerozolimskiej, w tym ks. Jełowicki. Podróż trwała od 3 lutego do 20 marca. Uczestnicy przez sześć dni zwiedzali zabytki Kairu i jego okolic. Dla ks. Jełowickiego szczególnie cenne poznawczo były pamiątki związane z faraonami biblijnymi. Głównym celem wyprawy była Góra Synaj. Droga powrotna profesorów i studentów przebiegała przez Gazę ${ }^{30}$.

Ze spraw akademickich należy również zauważyć, że ks. Jełowicki - o czym zresztą sam wspominał - był w czasie swojego pobytu w Jerozolimie świadkiem rodzenia się w środowisku szkoły czasopisma naukowego, będącego narzędziem wymiany myśli i osiągnięć w zakresie szeroko pojętych nauk biblijnych ${ }^{31}$. Pierwszy numer Revue Biblique ukazał się w styczniu 1892 r. Periodyk zaplanowany był na kilka zeszytów rocznie. Uczniowie szkoły należeli bez wątpienia do jego czytelników i komentatorów. Można sobie bowiem wyobrazić, że zawarte w czasopiśmie treści naukowe stanowiły przedmiot ożywionej dyskusji tak w ramach wykładów, jak i prywatnie ${ }^{32}$.

26 Jełowicki, Przechadzki po Jerozolimie, 1-33, 42-45, 51-54, 61-64, 78-86, 95-112.

27 Jełowicki, Przechadzki po Jerozolimie, 33-42, 45-51, 54-61, 64-68, 73-77, 86-95.

28 Jełowicki, Przechadzki po Jerozolimie, 112.

29 Couvent Saint-Etienne de Jérusalem, Registre 1882-1910, rok 1892.

30 Couvent Saint-Etienne de Jérusalem, Registre 1882-1910, rok 1893; Jełowicki, „Sześć dni w Kairze”, 673-678, 705-710.

31 „W klasztorze św. Szczepana dominikanie założyli szkołę praktyczną Biblii, gdzie przy studiach lingwistycznych i ciągłych oglądaniach kraju, studenci mogą lepiej nauczyć się thumaczyć Pismo św. Ojcowie posiadają oprócz tego wykłady filozofii i teologii według św. Tomasza. Biblioteka ich młoda jeszcze, lecz zanosi się na doskonałą, kwartalnik zaś „,Revue Biblique”, wydawany przez profesorów szkoły, podaje do wiadomości wszelkie nowsze odkrycia w dziedzinie geografii, topografii i archeologii biblijnej" (Jełowicki, Przechadzki po Jerozolimie, 115).

32 F.-M. Braun, L'oeuvre du Père Lagrange. Étude et bibliographie (Fribourg: Imprimerie SaintPaul 1943) 29-30. 
W Ziemi Świętej istniały także pewne możliwości konsultowania się z wybitnymi postaciami świata nauki, innymi niż wykładowcy szkoły, prowadzącymi na miejscu działalność badawczą. Przykładu dostarcza zaplanowane przez ks. Jełowickiego indywidualne spotkanie z Conradem Schickiem, niemieckim architektem $\mathrm{i}$ archeologiem. Tematem rozmowy były kwestie związane $\mathrm{z}$ tzw. łukiem Ecce Homo i płytami brukowymi z twierdzy Antonia ${ }^{33}$.

Warto jeszcze zwrócić uwagę na fakt, że szerszy wymiar edukacyjny miał także udział ks. Jełowickiego w ważniejszych momentach życia klasztoru dominikańskiego. Bez wątpienia składały się na nie odwiedziny znamienitych osób z grona duchownych i świeckich, którzy przybywali do Ziemi Świętej z pielgrzymką lub spełniali na miejscu powierzone im funkcje administracyjne i pasterskie. Przykładowo na poniedziałkowych konferencjach tematycznych, które miały charakter wydarzeń nie tylko naukowych, ale także kulturalnych i towarzyskich, byli obecni konsulowie generalni Austrii, Rosji, Włoch i co oczywiste z uwagi na proweniencję klasztoru, także Francji. Ten ostatni - Charles Ledoulx - był zresztą częstszym gościem szkoły, którą odwiedzał z racji świąt kościelnych i innych uroczystych okazji. Ostatniego dnia roku 1892 na spotkanie do szkoły przybył z życzeniami ówczesny melchicki patriarcha antiocheński, aleksandryjski i jerozolimski, bp Damaszku Gregorios II Youssef-Sayour. Na Wielkanoc zjawił się w Jerozolimie z pielgrzymką i zatrzymał w gościnie abp Patrick Vincent Flood z Port-of-Spain na angielskich Antylach. W ramach szczególnego wydarzenia, jakim był Międzynarodowy Kongres Eucharystyczny w Jerozolimie, odbywający się w dniach 14-25 maja 1893 r., do miasta przybyła wielka pielgrzymka francuska, włoska oraz liczni chrześcijanie wschodni. W szkole celebrowano wówczas liturgię w języku syryjskim, przewodniczył jej patriarcha antiocheński Syryjskiego Kościoła Katolickiego, bp Bejrutu Ignatios Aphram II Rahmani. Obecny był legat papieski na jerozolimskie obchody abp Reims, kard. Benoît-Marie Langénieux. W klasztorze w czasie kongresu mieszkał ponadto abp Lorenzo Carlo Pampirio z Vercelli ${ }^{34}$.

$\mathrm{Z}$ dużą dozą prawdopodobieństwa można przyjąć, że ks. Jełowicki spotkał w czasie swojego pobytu w Palestynie zarówno łacińskiego patriarchę Jerozolimy, jak i kustoszy Ziemi Świętej, którymi byli kolejno abp Luigi Piavi oraz o. Giacomo Ghezzi. Do Ziemi Świętej pielgrzymował także bułgarski biskup Michel Petkoff, wikariusz apostolski Tracji, którego ks. Jełowicki - o czym wspominał w pamiętnikach - miał okazję poznać w czasie jednej z wypraw naukowych ${ }^{35}$.

33 Jełowicki, Przechadzki po Jerozolimie, 84.

34 Couvent Saint-Etienne de Jérusalem, Registre 1882-1910, rok 1892, rok 1893.

35 „Idąc po konie znajdujemy inny zajazd, gdzie na kawę wstępujemy i z wielkim zdziwieniem widzimy tam w gronie księży biskupa w fioletach; po wzajemnych prezentacjach dowiadujemy się, że to biskup bułgarski ks. Petkoff, który ma tytuł biskupa Hebronu in partibus infidelium, zwiedzając Jerozolimę przyjechał obejrzeć swój tytuł, życzymy mu by prędko mógł tytuł zamienić na rzeczywistą posiadłość" (Jełowicki, Przechadzki po Jerozolimie, 91). 
Ksiądz Jełowicki uczestniczył także w lokalnie znaczących wydarzeniach kościelnych i religijnych na płaszczyźnie związków szkoły z dominikańską wspólnotą zakonną. Z kroniki klasztoru św. Szczepana wynika, że w związku z ogłoszeniem 8 września 1892 r. przez papieża Leona XIII kolejnej encykliki różańcowej Magnae Dei Matris cała wspólnota codziennie wieczorem - co było novum w zakresie dewocji - odmawiała tę modlitwę przed wystawionym Najświętszym Sakramentem. Natomiast 24 października 1892 r., w 400. rocznicę odkrycia Ameryki, wszystkie wspólnoty religijne wzięły udział w uroczystościach organizowanych przez kustodię franciszkańską w Jerozolimie w klasztorze Najświętszego Zbawiciela. Z kolei od 25 października celebrowano w klasztorze św. Szczepana uroczyste i rozbudowane co do programu triduum ku czci beatyfikowanych przez Leona XIII w 1891 r. dominikanek: Diany Andalo, Cecylii Cesarini oraz Amaty. W dniu 6 grudnia w kościele św. Anny miały miejsce główne jerozolimskie modlitwy żałobne w intencji właśnie zmarłego kard. Charlesa Lavigerie. Szczególne znaczenie i oprawę miały, co zrozumiałe, obchody ku czci św. Szczepana, patrona miejscowej wspólnoty zakonnej. Łączyły w sobie elementy pobożności i wydarzenia towarzyskiego gromadząc przedstawicieli wszystkich miejscowych łacińskich katolików ${ }^{36}$.

Uczestnictwo polskiego księdza w spotkaniach z osobistościami z różnych zakątków globu, jak również udział w bieżących wydarzeniach dotyczących wspólnoty wierzących, było bez wątpienia istotnym uzupełnieniem studiów. Należy bowiem zwrócić uwagę na fakt, że rosyjskie władze zaborcze w Królestwie Kongresowym, skąd ks. Jełowicki przybył, starały się ze wszech miar utrudnić kontakt miejscowego Kościoła z szerokim światem katolickim i wpłynąć w ten sposób na jego charakter. W tym przemyślanym działaniu chodziło zarówno o lojalizowanie ludzi i faktyczne podporządkowywanie sobie struktur eklezjalnych, jak i o wykluczenie zewnętrznych bodźców do ambitniejszego duchowego i organizacyjnego rozwoju Kościoła katolickiego zamkniętego w granicach carskiego państwa.

\section{Zastosowanie nabytej wiedzy}

Po zakończeniu roku akademickiego 1892/1893 w drugiej połowie maja, ks. Jełowicki wraz z ks. Chabotem opuścili szkołę ${ }^{37}$. W drodze powrotnej odwiedzili jeszcze Amwas, do którego udali się konno ${ }^{38}$. W miejscowości Ramla skorzystali z pociągu, którym dotarli do Jaffy, a stamtąd drogą morską - na pokładzie statku

36 Couvent Saint-Etienne de Jérusalem, Registre 1882-1910, rok 1892.
37 Couvent Saint-Etienne de Jérusalem, Registre 1882-1910, rok 1893.
38 Jełowicki, Przechadzki po Jerozolimie, 117-124. 
płynącego do Marsylii, a należącego do Compagnie des Messageries Maritimes odpłynęli, w nostalgicznych nastrojach - do Europy ${ }^{39}$.

Tak więc pierwszy Polak w dziejach szkoły przebywał w niej przez niecały rok. Czy można w tych okolicznościach mówić o ukończeniu podjętych studiów? Prawdą jest również, że w przeciwieństwie do studentów zakonnych, ks. Jełowicki nie podchodził do żadnych egzaminów. Zdawali je bowiem tylko dominikanie i asumpcjoniści. Wynikało to $\mathrm{z}$ faktu, iż nie odbyli oni wcześniej pełnego kursu filozoficzno-teologicznego. Przybywali bezpośrednio po nowicjacie, ewentualnie $\mathrm{z}$ niewielkim stażem studenckim. Uzupełniali zatem swoje studia w Jerozolimie i byli egzaminowani z typowych przedmiotów wykładanych dla alumnów. Nazwisko ks. Jełowickiego, inaczej niż kleryków zakonnych, nie zostało więc ujęte na listach zdających ${ }^{40}$. Tak czy inaczej kwestia ta nie powinna być traktowana zbyt formalnie. Zajęcia w szkole były często łączone, a program wciąż się jeszcze kształtował. Same studia nie kończyły się żadnym stopniem naukowym, a jedynie dyplomem poświadczającym ich sfinalizowanie.

Po powrocie do kraju ks. Jełowicki został najpierw prefektem w gimnazjum realnym w Warszawie. W 1901 r. otrzymał nominację na urząd proboszcza robotniczej parafii pw. Trójcy Świętej na warszawskim Solcu. Unowocześnił i zdynamizował tamtejsze duszpasterstwo - ożywił życie religijne i podniósł poziom nauczania. Rozwinął działalność społeczną, tworząc z własnych środków kapitałowych instytucje charytatywne i oświatowe - zakładał kuchnie dla ubogich, ochronki dla dzieci i w zasadzie tajne szkoły polskie. Poczynił inwestycje materialne - odrestaurował kościół parafialny, zbudował nową kaplicę służącą wiernym, zaczął wznosić świątynię parafialną pw. Matki Bożej Częstochowskiej na Powiślu. Otrzymał szereg stanowisk diecezjalnych i funkcji honorowych został mianowany szambelanem, a potem prałatem papieskim, wszedł w skład warszawskiej kapituły metropolitalnej, został radcą konsystorza, sędzią sądu arcybiskupiego i referentem spraw szkolnych ${ }^{41}$.

Co ważne, na każdym etapie życia prowadził działalność pisarską. Poza wspomnianymi publikacjami, będącymi bezpośrednim efektem pobytu i podróży po Ziemi Świętej, przygotowywał zarówno hasła słownikowe do Wielkiej encyklopedii powszechnej ilustrowanej oraz Podręcznej encyklopedii kościel$n e j$, jak też artykuły do czasopism - Przegladu Katolickiego, Tygodnika Ilu-

39 „Żegnamy się z Ziemią Obiecaną, przykro nam ją opuścić, bo człowiek przywiązuje się do miejsc świętych, które są jakby przedsionkiem raju" (Jełowicki, Przechadzki po Jerozolimie, 124).

40 École biblique et archéologique française de Jérusalem, Conseils. Studium Sancti Stephani Hierosolymitani. Liber examinum et exercitiorum scolasticorum. Registres (ACSEJ, sygn. 4E/A-1) 6-7; Registres et listes des étudiants. Liste des étudiants de l'École depuis la création. Liste alphabétique (ACSEJ, sygn. 4E/C-2) bez paginacji.

41 „J.E. Ks. Biskup A. J. Bożeniec Jełowicki, biskup tytularny lorymejski, sufragan lubelski”, WDL 1 (1919) 186-188. 
strowanego i Wędrowca. Z kilkudziesięciu opublikowanych w ten sposób opracowań większość dotyczyła problematyki biblijnej oraz archeologii i geografii Palestyny ${ }^{42}$.

Achille Ratti, wizytator apostolski w odradzającej się Polsce i zarazem późniejszy papież Pius XI, poznawszy osobiście ks. Jełowickiego w Warszawie, wyrażał się o nim z aprobatą w kontekście poszukiwania kandydatów do obsadzenia stolic biskupich ${ }^{43}$. W rezultacie 9 listopada 1918 r. ks. Jełowicki został mianowany sufraganem lubelskim. Sakrę biskupią przyjął w swojej parafii w Warszawie 23 marca 1919 r. z rąk biskupa kamienieckiego Piotra Mańkowskiego. W diecezji piastował urząd wikariusza generalnego, następnie oficjała lubelskiego sądu biskupiego, był prałatem archidiakonem, a potem prałatem dziekanem lubelskiej kapituły katedralnej, ale przede wszystkim przez prawie dwie dekady godnie i z oddaniem wypełniał zwyczajne zadania pasterskie w lokalnym Kościele. Zmarł w Lublinie 7 lipca 1937 r. ${ }^{44}$ Bez wątpienia rok spędzony w Ziemi Świętej, gdzie jako pierwszy z Polaków studiował w jerozolimskiej szkole biblijnej, stanowił cenny kapitał na całe jego kapłańskie życie, promieniując zarazem na wszystkich oddanych mu w duszpasterską pieczę.

\section{Bibliografia}

\section{Źródla archiwalne}

Akta osobowe bpa Adolfa Józefa Bożeńca Jełowickiego (Archiwum Archidiecezjalne Lubelskie, sygn. Rep 60 B IIb J31).

Couvent Saint-Etienne de Jérusalem, Registre 1882-1910 (Archives du Couvent Saint-Etienne de Jérusalem [=ACSEJ], sygn. 4C/D).

École biblique et archéologique française de Jérusalem, Conseils. Studium Sancti Stephani Hierosolymitani. Liber examinum et exercitiorum scolasticorum. Registres (Archives du Couvent Saint-Etienne de Jérusalem [=ACSEJ], sygn. 4E/A-1).

École biblique et archéologique française de Jérusalem, Registres et listes des étudiants. Liste des étudiants de l'École depuis la création. Liste alphabétique (Archives du Couvent Saint-Etienne de Jérusalem [=ACSEJ], sygn. 4E/C-2).

Dębiński, K., Z przė̇ytych chwil. Cz. 1 (maszynopis, Biblioteka Metropolitalnego Seminarium Duchownego w Lublinie, bez sygn.).

Protocolli (Archivio Segreto Vaticano, Archivio Nunziatura Varsavia, sygn. 192).

42 F. Stopniak, „Jełowicki Adolf Józef”, Stownik polskich teologów katolickich (red. L. Grzebień) (Warszawa: Akademia Teologii Katolickiej 1983) V, 596-597.

43 „Mons. Adolfo Jełowicki parroco in Varsavia l'uomo abbastanza istruito per pratico di curia e di cura d'anime e ciò che non nuoce ricco ed imparentato colle migliori famiglie" (Protocolli [Archivio Segreto Vaticano, Archivio Nunziatura Varsavia, sygn. 192] 445).

44 W. Goral, „Śp. ks. Adolf Józef Bożeniec Jełowicki sufragan lubelski (1863-1937)”, WDL 19 (1937) 344-347. 


\section{Opracowania}

Braun, F.-M.,L'oeuvre du Père Lagrange. Étude et bibliographie (Fribourg: Imprimerie Saint-Paul 1943).

Faucher, X., „École pratique d'études bibliques”, Revue Biblique 1/1 (1892) 126-132.

Goral, W., „Śp. ks. Adolf Józef Bożeniec Jełowicki sufragan lubelski (1863-1937)”, Wiadomości Diecezjalne Lubelskie 19 (1937) 344-351.

„J.E. Ks. Biskup A. J. Bożeniec Jełowicki, biskup tytularny lorymejski, sufragan lubelski”, Wiadomości Diecezjalne Lubelskie 1 (1919) 185-189.

Jełowicki Bożeniec, A.J., „Przechadzki po Jerozolimie i bliższych jej okolicach”, Kronika Rodzinna 27 (1894) 6-10, 70-72, 100-102, 139-142, 168-170, 201-203, 239-241, 263-266, 301-302, 338-341, 368-370, 388-390, 422-424, 465-467, 495-497, 520-522, 553-555, 588-590, 620-623, 654-656, 691-693, 716-718, 758-759.

Jełowicki Bożeniec, A.J., Przechadzki po Jerozolimie i bliższych jej okolicach (Warszawa: Nakład M. Orgelbranda 1897).

Jełowicki Bożeniec, A.J., „Sześć dni w Kairze”, Kronika Rodzinna 26 (1893) 673-678, 705-710.

Lagrange, M.-J., „Chronique. Après vingt-cinq ans”, Revue Biblique 12 (1915) 248-261.

Montagnes, B., Marie-Joseph Lagrange. Une biographie critique (Paris: Cerf 2004).

Le Père Lagrange au service de la Bible. Souvenirs personnels (Paris: Cerf 1967).

Séjourné, P.-M., „Chronique”, Revue Biblique 2 (1893) 119-145.

Stopniak, F., „Jełowicki Adolf Józef”, Słownik polskich teologów katolickich (red. L. Grzebień) (Warszawa: Akademia Teologii Katolickiej 1983) V, 596-598.

Vincent, L.-H., „Le Père Lagrange”, Revue Biblique 47 (1938) 321-354.

Wodzianowska, I., Rzymskokatolicka Akademia Duchowna w Petersburgu 1842-1918 (Lublin: Towarzystwo Naukowe KUL 2007). 
